\title{
A Political Economy Analysis of Income Diversification Activities of Rural Households in the Northern Region of Ghana
}

\author{
Gamel Abdul-Nasser Salifu ${ }^{1} \&$ Kwabena Asomanin Anaman ${ }^{2}$ \\ ${ }^{1}$ Lecturer, Department of Economics, Ghana Institute of Management and Public Administration, Achimota, Accra, \\ Ghana. \\ ${ }^{2}$ Professor, Department of Agricultural Economics and Agribusiness, College of Basic and Applied Sciences, \\ University of Ghana, Legon, Accra, Ghana.
}

Correspondence: Gamel Abdul-Nasser Salifu, Lecturer, Department of Economics, Ghana Institute of Management and Public Administration, Achimota, Accra, Ghana. E-mail: sgamel@ gimpa.edu.gh

Received: June 13, $2019 \quad$ Accepted: July 8, $2019 \quad$ Available online: July 26, 2019

doi:10.11114/aef.v6i5.4405 URL: https://doi.org/10.11114/aef.v6i5.4405

\begin{abstract}
This study analysed income diversification activities of 1,194 rural households in the Northern Region of Ghana using data from the sixth round of the Ghana Living Standards Survey (GLSS) undertaken by the Government of Ghana, through the Ghana Statistical Service. We found that $92 \%$ of rural households were engaged in farm activities affirming agriculture as the dominant profession of rural households in the region. The number of income-generating activities undertaken by these households was significantly related to the size of the household, previous apprenticeship training acquired by the household head, ownership of a motor bike/car, and ownership by the household of specific physical assets which also provide information, communication and entertainment services, namely mobile phone, radio and television sets. The share of wage-based income in the total household income was significantly related to the age of the household. The overall income diversification index was positively influenced by the level of remittances and the number of rooms in the house; the latter allowed for increased possibility of renting rooms in the house to workers. We also established that overall income diversification index was associated with decreasing total household consumption expenditures and reduced food security at relatively low levels. However, this index was linked to increasing household consumption expenditures and improved food security at relatively higher levels. Our findings suggest that income diversification could be an important poverty-reducing measure if well-designed Community and State support programmes for rural households are implemented in the region under conditions of peace and good security.
\end{abstract}

Keywords: diversification, Ghana, income diversification, non-farm income, Northern Ghana, off-farm income, poverty, rural households

\section{Introduction and Problem Statement}

\subsection{Country Historical Overview}

Ghana is an English-speaking nation state in West Africa with a population of about 30 million (July 2019 estimate) and a per capita gross domestic product (GDP) of about 2,214 United States dollars based on recently-released rebased GDP figures which use 2016 as the base year (Ghana Statistical Service, 2019). The country was originally called the Gold Coast by European nation-state powers due to the extensive gold deposits found along its coasts and hinterland by European explorers and merchants. From the last quarter of the $15^{\text {th }}$ Century to the end of the $19^{\text {th }}$ Century, various European nations actively competed for the control of trade along the coast of West Africa and its hinterland, for gold, palm oil, other commodities, and human slaves (Ellis, 1894; Ward, 1948). The Trans-Atlantic African slave trade started in 1619, exactly 400 years ago. One of its major trading centres was the Gold Coast area, exemplified by over one-third of all the slave castles and forts, built by various European State agencies in Africa, found along the coastal line of Ghana. Historians suggest that the effective abolition of the Trans-Atlantic slave trade in the $19^{\text {th }}$ Century led to its substitution with trade in oil palm, and other commodities, increased international trade diversification, and reduced levels of inter-state conflicts in West Africa, for example, refer to the work of Kah (2013, pp. 109-110).

The European nations which traded along the Gold Coast included Portugal, Denmark, France, Germany, Great Britain and the Netherlands (Ellis, 1894; Ward, 1948). By the start of the $19^{\text {th }}$ Century, Great Britain had emerged as the 
strongest European power in the Gold Coast area. It signed a treaty of friendship and joint security with 17 coastal and near-coastal traditional African states on 6 March $1844 .{ }^{1}$ Throughout the rest of the $19^{\text {th }}$ Century, the British were able to extend their influence in this area with the conquest of some traditional African states, and through negotiations with various kingdoms, completed in 1902. These traditional states were added to the existing Gold Coast entity established in 1844 to form one unitary state. The British had formally declared the Gold Coast entity a colony in 1874. In 1956, with the completion of the United Nations-organised referendum for Trans-Volta Togoland (TVT), TVT became a part of the Gold Coast colony during that year. Political independence was achieved on 6 March 1957, with the country renamed Ghana.

The struggle for political independence of the Gold Coast started in March 1865 by a Movement led by King Aggrey of Cape Coast; the latter town was the site that the original 6 March 1844 treaty was signed (Lynch, 1968; Nti, 2002). The final leg of the 92-year political independence struggle journey from March 1865 to March 1957 was led by Dr. Kwame Nkrumah and the Convention People's Party (CPP) from 1949 to 1957 (Buah, 1998; Davidson, 1972). Ghana became a Republic, within the Commonwealth of English-speaking Nations, on 1 July 1960, after national presidential election held in the same year which was won by Dr. Nkrumah and the CPP. ${ }^{2}$

The current northern part of the country was initially one region at the beginning of the $20^{\text {th }}$ Century. The acquisition of this territory by the British Government was through negotiations with the principal chiefs of the area to join the existing Gold Coast Colony. These negotiations were completed in 1902. This was different from several parts of the country where the British used military force to conquer various kingdoms which were then added to the original Gold Coast State during the Scramble of Africa era formalized by European nations through the 1884-1885 Berlin Conference of nation states (Ellis, 1894; Davidson, 1972; Buah, 1998). The Northern Territory had continuously-extensive people-to-people contacts with the neighbouring northern countries of Burkina Faso, Mali, Niger, and Nigeria, and shared aspects of common culture such as the Hausa language (Gatawa, 2013), a language widely spoken in Ghana and parts of West Africa.

The old Northern Territory was divided into three new regional entities after independence namely Upper East, Upper West and Northern Regions. The Northern Region, the area of this current study, was divided into three new regions in 2019 based on referenda organized in specific parts of the region to create three new regions out of the old region on 27 December 2018 (Zurek, 2018). These new regions are: (1) Savannah Region, (2) Northeast Region, and (3) Northern Region. ${ }^{3}$ Our study relied on data from the sixth round of the GLSS, completed in 2013, which was the last major living standards survey of the Ghana Statistical Service for which the data have been fully released to the public for research work. Data from the seventh round of the GLSS completed at the end of 2017 have not been fully released to the public for detailed research work. Our current study covers all three new regions of the old Northern Region using GLSS6 data.

\subsection{Problem Statement}

Overall, the results from the GLSS6 completed in 2013 by the Ghana Statistical Service confirmed the findings of previously-released national living standards surveys that the regions situated in the northern part of the country had the highest poverty levels in Ghana. Absolute poverty defined as the inability of a householder to consume the equivalent of 1.25 dollars per day, had remained consistently above 50\% for this part of the country (Ghana Statistical Service, 2014). At the regional level in Ghana, the Northern, Upper East and Upper West Regions continued to have the highest poverty rates in Ghana. However, both Upper East and Upper West regions, and the other regions in Ghana, had seen significant declines in poverty rates over time. The Northern Region had the smallest poverty reduction of all regions in Ghana and also had the largest number of poor people for all the ten old regions estimated to be about 1.3 million.

The persistent poverty in Northern Ghana has engaged policymakers since political independence in 1957, and they have introduced a number of policy measures to solve this problem. For example, formal education has been made free from primary school to secondary school, including coverage for boarding and lodging facilities in secondary schools, for residents of the northern part of the country, since independence. Over the last 62 years, Northern Ghana has also benefitted from several programme interventions of the government, and local and overseas community organizations, including faith-based Christian and Muslim associations. Recent initiatives by the government have included the establishment of a specific development authority to undertake programmes to advance the living standards of people in the northern part of the country.

Agriculture is the dominant source of income in the northern part of Ghana, especially in its rural areas (Ghana Statistical Service, 2014). However, unlike the relatively wealthier southern regions which have two rainy seasons, Northern Ghana has only one rainy season, and also has very limited irrigation infrastructure to handle all-year-round production of crops. Given the relatively poor natural capital resources, one way to reduce poverty in Northern Ghana, which contains about one sixth of the country's population (five million people), is for the diversification of income sources through expanded access to community resources and governmental support systems that can assist them to 
earn incomes from a variety of sources. Income diversification has not yet benefitted majority of rural households in Northern region of Ghana where poverty is endemic. Poverty gaps are increasing with yield gaps resulting from persistent low farm productivity amidst chronic food insecurity (Dzanku et al., 2015).

Income diversification by rural households in the Northern Region of Ghana is not divorced from the underlying political economy issues in the region. These issues are related to land control and ownership, and the struggle for environmental resources amidst the effects of changing climate and an encroaching Sahara Desert. In 2009, Mohammed Sulemana published a paper in the Ghana Policy Journal based on a wide-ranging survey of people in the Northern Region of Ghana, which identified the causes of the persistent inter-ethnic and intra-ethnic conflicts in the region. He indicated that the control and ownership of land, perceived historical injustices, and marginalization felt by some social/ethnic groups, were among the leading causes of these conflicts. He also argued that the conflicts contributed considerably to the overall high poverty situation in the region due to their destructive impacts and the reduction of income diversification activities.

\subsection{Objectives of the Study}

Given the background, the three main objectives of this study were (1) to identify the various income-generating sources of rural households, (2) to establish the various factors influencing the degree of income diversification of rural households, and (3) to ascertain the linkage between income diversification and rural household economic welfare, in the Northern Region of Ghana, using data from the GLSS6. This paper contributes to the international literature on economic growth with emphasis on poverty reduction through income diversification as a means of reducing overall household livelihood risks and vulnerabilities. The rest of this paper is organized as follows: the next section deals with a brief review of the literature concerning the topic including underlying political economy theories used for this study. This is followed by a description of the methodology including data sources and statistical analysis. The results are presented in the fourth section. This is followed by the conclusions, recommendations, a list of cited references and five endnotes.

\section{Literature Review}

\subsection{Introduction}

Income diversification has been championed as an important policy strategy that can provide a pathway out of poverty and promote sustainable economic growth in Africa (World Bank, 2013). Income diversification in a rural economy entails the pursuit of other income-generation strategies at different levels of the rural economy in addition to the primary economic activity, which is often agriculture (see for example, the works of Agyemang et al., 2014; Timmer, 2009; Davis et al., 2009; Ellis and Freeman, 2006; Bird and Shepherd, 2003; Start, 2001). Several welfare indicators of income diversification exist. These include: a positive relationship between non-farm income and rural household welfare indicators such as consumption (Barrett and Reardon, 2000), a positive relationship between non-farm income and farm productivity and food security (de Janvry and Sadoulet, 2006), and a strategy deployed to minimize risks associated with farming (de Janvry and Sadoulet, 2001). Non-farm income reduces overall inequality (Winters et al. 2010; Canagarajah et al., 2001), and ensures upward mobility of rural households (Ellis and Freeman, 2006).

In contrast, rural households which lack non-farm incomes are often vulnerable and their food security is worsened by seasonal changes in food prices and in production cycle (Winters et al., 2010; Canagarajah et al., 2001). While income diversification can be a way of reducing poverty, Haggblade et al. (2010) have cautioned that income diversification policies of governments tend to favour better-off farmers who have sufficient assets and connections to the political power structures. Government income diversification programmes for rural households could therefore be counterproductive unless they are well structured and targeted; this brings to the forefront political economy issues of income diversification.

\subsection{Political Economy Theories of Income Diversification}

Understanding the complexities of the real world of income diversification activities of rural household requires various analytical lenses that are assembled in a complementary manner to delve into critical questions related to these activities. A political economy study incorporates some historical analysis of issues, the assembly of various social science theories as complementary analytical lenses to evaluate issues in a more holistic manner, rather than an overbearing use of a single economic theory to explain such issues. Political economy analysis emphasizes the inter-related nature of the capacity of a household, its constraints, and the choices that it can make. Political economy theories used for the analysis of income diversification include: (1) sustainable livelihood framework, (2) risk management theories, and (3) structuralism theories.

The failures of people to earn adequate incomes from their livelihoods to take care of themselves and their families are considered as market failures in economics science. These are linked to the three Cs of political economy analysis: (1) capacity, (2) constraints and (3) choices. Market failures are often related to insufficient levels of capital inputs that 
reduce the capacity of a household to produce adequate incomes via the sustainable livelihoods framework. This framework provides an approach in studying the issue of income diversification among rural households by the recognition of the availability and use of capital inputs to produce incomes (Ashley and Carney, 1999; Buadi et al., 2013). If a person does not have sufficient levels of capital inputs, then adequate incomes cannot be produced to support himself/herself and his/her family using legal and socially-acceptable means. Insufficient levels of capital inputs could also be the result of civil conflicts which render available capital inputs unusable to produce goods and services (Sulemana, 2009).

The major pioneering works of Knight (1921), von Neumann and Morgenstern (1944), Markowitz (1952), and Tobin (1958a), laid the essential mathematical economic foundations of the common worldwide saying and often-quoted proverb that individuals are not likely to put all their eggs in one basket in order to minimize livelihood risks. Income diversification is a common risk management strategy of African farmers (Anaman, 1988). Market failures could be the result of weak support systems of people to bear the risks of production, via the risk management framework, (Awo and Anaman, 2015), which could also be due to civil conflicts (Sulemana, 2009). Income diversification involves an increase in income sources and a balance of these sources in the household income-producing portfolio. It is associated with increasing income security under low-risk economic conditions as well as coping with livelihood and income distress under high- risk conditions (Ellis and Freeman, 2006). Diversification is the process by which rural households generate income from different sources to increase income portfolios (Niehof, 2004). As noted by Barrett and Reardon (2000), income diversification is a risk mitigation strategy wherein rural households are able to self-insure against high-risk activities such as agriculture. Rural households with excellent support systems have well diversified sources of income and experience less income variability in incomes than other households with relatively weak support systems.

Structuralism theories indicate that the dominant social/ethnic groups shape and/or determine societal outcomes within the nation state (Sackrey et al., 2016). Further, members of relatively small social/ethnic groups tend to be under-represented in key positions in the political arena which shape the socio-economic development of a country and these people are more likely to be marginalized. In Ghanaian situations, such marginalization often results from exclusionary practices, denoted in the local Akan language parlance, as the "kokofu game" or "kokofu political economy game" (Anaman and Bukari, 2019). Market failures faced by some people, especially those from small and marginalized groups, could also be due to entrenched exclusionary conditions that they encounter. These conditions are sometimes due to persistence of civil conflicts which often have deeply-planted historical roots. These exclusionary conditions reduce the capacity of a household to undertake income diversification activities limiting its production and marketing choices.

Variables used in structuralism political economy analysis include disability status, aged, chronically-sick people, low-income and poor people, ethnicity, relatively small minority social/ethnic group status, political party membership, closeness to political power structures, membership of influential royal families, chieftaincy status, religious affiliation, migrant status, marital status, racial group, and sex/gender groupings including transgender classifications. In a recent Ghanaian cocoa farmers' case study, it was established that female and Muslim cocoa farmers were more likely to be excluded from an income-enhancing mass cocoa spraying programme that they contributed to its financing based on deductions from the gross cocoa price (Anon., 2019, p. 44). For the case of marital status, a common structuralism political economy hypothesis, based on the adaptation of economic theories of marriage, developed by Becker (1973, 1974), suggests that one partner in a marriage setting normally specializes in market activity while the other undertakes household activity (for example, refer to the works of Anaman and Kassim, 2006; Mohammed and Anaman, 2003). Hence income diversification could be less intense for household heads who are married as compared to those not married.

\section{Methodology}

We integrated all the above-mentioned three frameworks in our methodology. This integration, via model building, and statistical and econometric analysis, is discussed in this section.

\subsection{Sustainable Livelihoods Framework}

The Sustainable Livelihoods (SL) concept is one of the three theoretical frameworks underpinning this study. A sustainable livelihood results from the use of adequate levels of capital inputs. Capital inputs are categorized into seven major forms in our study as follows: (1) Environmental and natural capital, (2) Household energy and water access capital, (3) Human capital, (4) Physical capital, (5) Financial capital, (6) Social capital, and (7) Informational capital. Environmental and natural capital denotes land and related factors which also may include the presence of pests in the natural environment that renders the use of land inefficiently. For example, the presence of black fly and fall armyworms, which are common in the Northern region of Ghana, reduce the capacity of the natural environment to produce adequate incomes. Since the dawn of humankind about 200,000 years ago in Eastern Africa, and the start of 
agriculture 10,000 years ago in Ethiopia (Diamond, 1999), household energy and water access capital inputs have been among the most important capital inputs required for the production of income and survival of human beings, the homo sapiens species of animals (refer also to the works of Mcbrearty and Brooks (2000) and others compiled by Wikipedia (2019).

We extend the above-mentioned SL capital inputs framework by expanding on the informational capital with a new concept called the information, communication and entertainment (ICE) capital. ICE capital refers to capital inputs which have multipurpose functions in four areas: (1) information, (2) communication, (3) entertainment and (4) store of wealth. Examples of ICE capital inputs include radio and television sets, and mobile phone. These assets are widely available in many rural areas of Ghana and serve as important sources of information about various income livelihood activities in rural areas such as farming, marketing and home-based enterprises. ICE capital inputs also provide means through which rural people can communicate and receive ideas, for example, through radio and television farming programmes and talk shows where people call into various programmes to share ideas. Further, these assets are used as store of wealth by rural householders in Northern Ghana. Our approach analyses these assets, not only as a store of wealth like cattle as used in the traditional development literature in Africa, but also as inputs used to generate goods and services made possible by the multi-purpose nature of these assets.

These ICE capital inputs are an important source of entertainment services in areas such as music, dance and movies. It is common to see many farmers in the Northern region of Ghana listening to music via their radio sets while they are busy undertaking farming activities and also while taking break from these farming activities. Mobile phones also provide access to various information products, allow for regular communication to people to search for information for livelihood activities, and through its download options, provide music and related entertainment services. The entertainment services provided by ICE capital also serve to improve upon the psychological status of rural beings allowing them to engage in their primary livelihood activities with more ease and comfort. ICE capital inputs, because of their current widespread availability, are included in our models to investigate their effects on income diversification activities.

\subsection{Risk Management Framework}

Closely-related to the SL framework, we also use the approach of income diversification as a risk management strategy. Individuals use their assets in several ways to generate incomes. The approach used in our study is to analyse whether income diversification decreases or increases the level of poverty and food insecurity. This is undertaken by an analysis of the relationship between overall income diversification of households and their economic welfare positions measured by total consumption expenditures, and food expenditures.

\subsection{Structuralism Political Economy Framework}

As indicated earlier, structuralism theories indicate that the dominant social and economic groups determine or significantly shape social and economic outcomes in any society. In the case of Northern region of Ghana, based on customs and traditions, it is more likely that in a marriage setting, the female spouse(s) specializes in household activity while the male spouse engages in wage-based non-farm activity. Both partners may also engage in farming activities. We expect that income diversification activities in the Northern region of Ghana have sex-based influential dimensions. Ethnicity could be a factor in income diversification, and is included in our analysis.

\subsection{Data and Data Sources}

The data came from the sixth round of the GLSS which was completed in 2013 after a whole-year random-sampling survey of households covering all the regions of Ghana. These data have been fully available to the public for research work since 2015. The GLSS is a regularly-repeated nationwide survey undertaken by the Government of Ghana through the Ghana Statistical Service. It employs state-of-the-art scientific sampling techniques which make its data useful for empirical analysis dealing with economic welfare of the citizens and residents of Ghana. The data for our analysis are restricted to the Northern Region of Ghana as per the arguments presented in the problem statement. This means that only 26 districts out of the then 216 districts in Ghana are covered in our analysis. Further, we restricted our analysis to only the rural parts of the Northern Region. Thus, 1,194 randomly-selected households in the Northern Region were available for analysis. Based on the available GLSS6 data released to the public for research work, we identified several variables that could affect income diversification. The variables cover six of the seven major capital inputs groups namely Household energy and water access capital, Human capital, Physical capital, Financial capital, Social capital, and ICE capital inputs. These 27 household variables were available from the GLSS6 data and are described in the next section.

\subsection{Concepts Dealing with the Statistical Analysis of Income Diversification}

Following the works of Minot et al. (2006), Sultana et al. (2015), Amurtiya et al. (2016), Wan et al. (2016) and Daud et al. (2018), the approach used in this study focussed on several statistical measures of income diversification. We 
established six main sources of income-generating activities as follows: (1) crop and livestock (farm) production, (2) home or community-based non-farm enterprises, (3) wage-based income activities through undertaking selling one's labour time on work activities outside the household, (4) property-based rental income such as those derived from renting rooms of the household property, (5) remittances from various social networks, and (6) other sources. For each of the six income sources, its share of the total household income is derived as the specific income divided by the total household income. Intuitively, all the six shares add up to 1.0 based on the laws of probability. Our analysis on the share of the total household income attributed to various sources was limited to the most important non-farm activity, wage-based off-farm work (SHAREWAGE) which consisted of about $70 \%$ of total non-farm income.

We also used a diversification index related to the well-known Herfindahl-Hirschman Concentration index (HHCI) (Hirschman, 1945; Herfindahl, 1950; Herfindahl, 1959; Hirschman, 1964: Hall and Tideman, 1967). This overall diversification index is called the Simpson index (Simpson, 1949). It accounts for the overall diversification of all income sources. The HHCI measures the overall concentration of all income-generating activities. It is derived by the sum of squares of income shares from each income-generating source as a proportion of total income. The Simpson diversification index (SDI) is 1-HHCI. It measures the overall spread of all activities with respect to their importance in an income-generating portfolio. A high SDI implies a high degree of income diversification as compared to a low SDI. The SDI is calculated for each individual household and is indicated in Equation 1.

$$
\text { SDI }=1-\Sigma \mathbf{P i}^{2}
$$

Equation 1

where SDI is the Simpson overall diversification index for a household.

$\mathrm{Pi}$ is the share of total gross income of a household generated from income source $\mathrm{i}$.

Note that the Herfindahl-Hirschman concentration index, HHCI for a household, is denoted by $\Sigma \mathrm{Pi}^{2}$.

The three income-diversification measures, NIGS, SHAREWAGE, and SDI were the designated dependent variables. Each dependent variable was regressed on a number of socioeconomic variables (independent variables). The independent variables are derived from the various groups of capital inputs based on the sustainable livelihood framework, risk management, and structuralism political economy frameworks discussed earlier. The 27 independent variables are listed as follows:

EDUCATION is the number of years of formal schooling education acquired by household head.

SEX is a dummy variable for sex of household head with 1 denoting female and zero for male.

CURRENTLYMARRIED is a dummy variable for the current marital status of the household head with 1 denoting that the household head is currently married and zero denoting otherwise.

AGE is the age of the household head in years.

AGESQ is the square of age and is considered as an additional variable to capture the effect of increasing age on the level and nature of income diversification.

HOUSEHOLDSIZE is the number of persons living in one household.

APPRENTICE is a dummy variable with 1 indicating that the household head has had apprenticeship training and zero for the lack of apprenticeship training.

REMITTANCE is the amount of money received during the calendar year by the household head as remittances from various local and overseas social networks.

MUSLIM is a dummy variable with 1 referring to the household head being a Muslim and zero for non-Muslim.

FETCHWOOD is a dummy variable indicating whether the household relies on a member to fetch firewood for energy use with 1 referring to households engaged in such a practice and zero for households not engaged in such a practice.

OWNHOUSE is a dummy variable for ownership of the residential house by the household head with 1 referring to ownership and zero for lack of ownership.

ROOMS is number of rooms available in the house occupied by the household.

ELECTRICITYCONNECTION is a dummy variable with 1 indicating connection of electricity from the national grid to the household and zero for no electricity connection.

TIMETOWATERSOURCE is amount of time spent in minutes by household members to fetch water from the nearest source of drinking water.

MOBILEPHONE is a dummy variable with 1 indicating ownership of one or more mobile phones by adult members of the household and zero for no ownership of mobile phones by the household.

RADIO is the availability of radio in the household. It is a dummy variable with 1 referring to ownership of radio sets 
and zero indicating no ownership of radio within the household.

TV is a dummy variable with a value of 1 for ownership of a television set by household members and zero for lack ownership of television set by household members.

COMPUTER is a dummy variable with a value of 1 for ownership of a computer by any household member and zero for lack of ownership of a computer by any adult household member.

SEWINGMACHINE is a dummy variable with a value of 1 for ownership of a sewing machine by the household and zero for lack of ownership of sewing machine by the household.

BICYCLE is a dummy variable with a value of 1 for ownership of a bicycle by an adult household member and zero for the lack of ownership of bicycle by any adult household member.

CAR is a dummy variable with a value of 1 for ownership of a motor bike or car by the household and zero for the lack of ownership of a motor bike or car by any adult member of the household.

DAGOMBA is a dummy variable with a value of 1 for the household head being a Dagomba and zero if the household head is not a Dagomba.

KOKOMBA is a dummy variable with a value of 1 for the household head being a Kokomba and zero if the household head is not a Kokomba.

GONJA is a dummy variable with a value of 1 for the household head being a Gonja and zero if the household head is not a Gonja.

MAMPRUSI is a dummy variable with a value of 1 for the household head being a Mamprusi and zero if the household head is not a Mamprusi.

DAGARTE is a dummy variable with a value of 1 for the household head being a Dagarte and zero if the household head is not a Dagarte.

BIMOBA is a dummy variable with a value of 1 for the household head being a Bimoba and zero if the household head is not a Bimoba.

These 27 variables were classified into various groups of capital inputs. Via the SL framework, the three household energy and water access capital variables were ELECTRICITYCONNECTION, TIMETOWATERSOURCE and FETCHWOOD. The four human capital variables were AGE, AGESQUARED, EDUCATION and APPRENTICE. The six physical capital variables were OWNHOUSE, ROOMS, CAR, COMPUTER, SEWINGMACHINE and BICYCLE. The financial capital variable was REMITTANCE. The social capital input was HOUSEHOLDSIZE, due to common presence of extended family and clan lineage members, plus nuclear family members, within the household. The three ICE capital inputs were MOBILEPHONE, RADIO and TV. The nine structuralism political economy variables integrated into the models were (1) sex of the household head (SEX dummy variable), (2) whether the household head was married or not (CURRENTLYMARRIED dummy variable), (3) whether household head was a Muslim or not (MUSLIM dummy variable), (4) DAGOMBA ethnicity variable, (5) KOKOMBA ethnicity variable, (6) GONJA ethnicity variable, (7) MAMPRUSI ethnicity variable, (8) DAGARTE ethnicity variable and (9) BIMOBA ethnicity variable.

\subsection{Poisson Regression Analysis of Income Diversification Based on NIGS}

For the regression model using NIGS, this is a count data model with the number of income-generating sources varying from one to six. Hence, the proper estimation procedure is through the Poisson regression model. We assume that $\mathrm{Y}$, the number of income-generating activities of household heads (NIGS) is a Poisson random variable with parameter $\lambda$, being both its mean and variance. The probability density function of the Poisson function is denoted in Equation 2 below (where exp denotes an exponential function)

$$
\mathbf{P}(\mathbf{Y}=\mathbf{k})=\exp ^{-\lambda} \lambda^{\mathbf{k}} / \mathbf{k} \text { ! }
$$

Equation 2

The Poisson regression function assumes that $\lambda$ is a function of the matrix of the independent variables $(\mathrm{X})$ defined earlier. This also implies that the conditional mean of $\mathrm{Y}$ is an exponential function of $\mathrm{X}_{\mathrm{i}} \beta$ where $\beta$ are the parameters as shown below in Equation 3.

$$
\lambda_{i=} \exp \left(X_{i} \beta\right)
$$

Equation 3

The Poisson regression model was estimated by the use of maximum likelihood method procedures available through the Time Series Processor software (Hall \& Cummins, 2009). The theoretical foundations of the Poisson regression model are described in details by Gujarati (2003, pp. 620-622). The empirical estimation of the Poisson regression model in our study, based on Equations 2 and 3 for $\lambda_{\mathrm{i}}$, is denoted in Equation 4 below. 


\section{$\lambda_{i=} \exp \left(\beta_{0}+\beta_{1}\right.$ HOUSEHOLDSIZE $+\beta_{2}$ AGE $+\beta_{3}$ AGESQUARED $+\beta_{4}$ SEX $+\beta_{5}$ YEARSOFEDUCATION $+\beta_{6}$ APPRENTICE $+\beta_{7}$ CURRENTLYMARRIED + $\beta_{8}$ MUSLIM $+\beta_{9}$ REMITTANCE $+\beta_{10}$ FETCHWOOD + $\beta_{11}$ OWNHOUSE $+\beta_{12}$ ROOMS $+\beta_{13}$ ELECTRICITYCONNECTION $+\beta_{14}$ TIMETOWATERSOURCE $+\beta_{15}$ MOBILEPHONE $+\beta_{16}$ RADIO $+\beta_{17}$ TV $+\beta_{18}$ SEWINGMACHINE $+\beta_{19}$ COMPUTER $+\beta_{20}$ BICYCLE $+\beta_{21}$ CAR $+\beta_{22}$ DAGOMBA $+\beta_{23}$ KOKOMBA $+\beta_{24}$ GONJA $+\beta_{25}$ MAMPRUSI + $\beta_{26}$ DAGARTE $+\beta_{27}$ BIMOBA)}

Equation 4

\subsection{Tobit Regression Analysis of Income Diversification Based on Shares of Total Incomes}

The regression model involving the second diversification measure, was estimated using the Tobit regression procedure given the relatively large number of zeros for each of the two dependent variables indicating unobserved situations. The original Tobit model developed by Professor James Tobin (1958b) is useful under conditions of non-observability of variables sometimes due to censoring (Maddala, 1992, pp. 338-342; Gujarati, 2003, pp. 616-619). This relatively large number of zeros is due to situations where some households do not have any off-farm income generating activities. The use of the standard ordinary least squares regression model is inappropriate as the error term would not be normally distributed. The Tobit model for SHAREWAGE is expressed in Equation 5 below:

$$
\mathbf{Y}^{*}=\left(\mathbf{X}_{\mathbf{i}} \boldsymbol{\beta}\right)+\mathbf{U}
$$

Equation 5

where $\mathrm{Y}^{*}$ is Tobit latent value for the dependent variable (SHAREWAGE)

$\mathrm{X}$ is the matrix of the 27 independent variables described above;

$\beta \mathrm{i}$ is the vector of regression parameters or coefficients; and

$\mathrm{U}$ is the vector of error term.

The Tobit regression functions for SHAREWAGE, and also for SDI, were estimated based on the maximum likelihood procedures and using the Time Series Processor software (Hall \& Cummins, 2009).

\section{Results}

\subsection{Description of Socio-economic Characteristics of Survey Respondents}

Table 1 provides information about socio-economic characteristics of the 1,149 randomly-selected households. Over nine out of ten household heads were men suggesting a male-dominated society. The majority of the household heads were in the 20 to 49 age group (64.6\%). About seven out of ten household heads were married. Two-thirds of household heads had no formal education. The dominant religious affiliation was Islam (Muslim), with almost three out of four respondents practising Islam. Whereas Christianity is the dominant religion in Ghana, the Northern religion is the only region where Islam is the dominant religion with about $60 \%$ of the population of the region being Muslims (Ghana Statistical Service, 2013). About one-third of the respondents were Dagombas, the largest social/ethnic group in the region. Kokombas are the next largest group followed by Gonjas and Mamprusis. Based on the more reliable ethnicity data from the 2000 national census, Dagombas and Kokombas are among the ten largest social/ethnic groups in Ghana. ${ }^{4}$

About one-quarter of the households had access to electricity energy compared to the national average for rural areas of 39.5\% of households in 2010 (Ghana Statistical Service, 2013). Fetching firewood was indicated by a relatively small proportion of household heads (13.8\%). Slightly over half of these rural households indicated that their principal source of water was protected wells. Ten percent of the households had directly-connected pipe borne water supply into their homes. Fetching water was indicated by only $10.2 \%$ of household heads. In terms of ownership of assets, about $71.2 \%$ of respondents had their own houses. This proportion is high compared to the national average of $47.2 \%$ reported for the 2010 National Population Census by the Ghana Statistical Service (2013). Further about 70\% of these houses had two to five rooms, a statistic which is also much higher than the national average of $49.8 \%$ reported for 2010 by the Ghana Statistical Service (2013).

Almost one out of four households (24.9\%) owned a motor bike or a car. This ownership rate for motor bikes/cars was one of the highest for rural areas in Ghana. Ownership of bicycles was also relatively high with almost seven out of 10 household heads having a bicycle (68.2\%). The ownership of ICE capital inputs was also generally impressive. At the time of the survey in 2013, almost six out of 10 households had at least one radio set, and a further $63.3 \%$ of households owned at least one or more mobile phones. These rates of ownership of ICE capital inputs would have likely increased in 2019. The ownership of television sets was relatively low at 13.3\%, less than one in seven households.

Table 1 also provides information about various income-generating sources of households. Over nine out of 10 households earned incomes from various agricultural activities. The proportion of household heads receiving rental income was higher at $99.2 \%$ with virtually all households (household heads) receiving some rental income. However the share of the average total household income attributed to rental income was only $8.3 \%$. Given that gross income from agricultural activities constituted $60.6 \%$ of total household income, the area of the study could be regarded as 
largely agriculturally-oriented in nature. The remaining $39.4 \%$ of the total household income came from non-farm sources.

Table 1. Summary of Socio-Economic Characteristics of Rural Survey Respondents (Household Heads) Based on Frequency Analysis Using Percentages for Specified Groups

\begin{tabular}{|c|c|}
\hline Socio-Economic Characteristic of Household Head & Percentage \\
\hline \multicolumn{2}{|l|}{ Sex of Household Head } \\
\hline Male & 91.7 \\
\hline Female & 8.3 \\
\hline \multicolumn{2}{|l|}{ Age Group of Household Head } \\
\hline Below 20 years & 1.0 \\
\hline Between 20 to 29 years & 15.0 \\
\hline Between 30 and 39 years & 27.1 \\
\hline Between 40 and 49 years & 22.5 \\
\hline Between 50 and 59 years & 14.2 \\
\hline Between 60 and 69 years & 10.8 \\
\hline Between 70 and 79 years & 7.6 \\
\hline 80 years and above & 1.8 \\
\hline \multicolumn{2}{|l|}{ Marital Status of Household Head } \\
\hline Currently Married & 87.6 \\
\hline Not Currently Married & 12.4 \\
\hline \multicolumn{2}{|l|}{$\begin{array}{l}\text { Level of Formal Educational Attainment of Household } \\
\text { Head }\end{array}$} \\
\hline None/No Schooling & 66.7 \\
\hline Completed some years of primary school & 7.3 \\
\hline Completed primary school but not junior secondary school & 5.6 \\
\hline $\begin{array}{l}\text { Completed junior secondary school but not senior secondary } \\
\text { school }\end{array}$ & 6.1 \\
\hline Completed senior secondary school & 3.0 \\
\hline Completed post-secondary/technical school & 1.4 \\
\hline Have University qualifications & 1.3 \\
\hline Formal adult educational and literacy qualifications & 8.5 \\
\hline \multicolumn{2}{|l|}{ Household Head Has Received Apprenticeship Training } \\
\hline Yes & 6.4 \\
\hline No & 93.6 \\
\hline \multicolumn{2}{|l|}{ Religious Affiliation of Household Head } \\
\hline Islam & 73.7 \\
\hline Christian & 21.2 \\
\hline No religion/traditional religion & 5.1 \\
\hline \multicolumn{2}{|l|}{ Ethnic Origin of Household Head } \\
\hline Dagomba & 32.0 \\
\hline Kokomba & 23.6 \\
\hline
\end{tabular}




\begin{tabular}{|c|c|}
\hline Gonja & 10.7 \\
\hline Mamprusi & 6.5 \\
\hline Dagarte & 5.6 \\
\hline Bimoba & 4.7 \\
\hline Basare & 2.4 \\
\hline Nakensi/Talensi/Gurense (Frafra) & 1.7 \\
\hline Guans from Yeji, Krachi, Nchumuru and five more areas & 1.5 \\
\hline Nanumba & 1.3 \\
\hline Chokosi & 1.2 \\
\hline Other Grusi & 1.0 \\
\hline Mosi & 0.9 \\
\hline All other groups (67 altogether) & 6.9 \\
\hline \multicolumn{2}{|l|}{ Ownership of House } \\
\hline Yes & 71.2 \\
\hline No & 28.8 \\
\hline \multicolumn{2}{|l|}{ Number of Rooms in the House } \\
\hline One & 20.6 \\
\hline Two & 34.7 \\
\hline Three & 21.2 \\
\hline Four & 13.0 \\
\hline Five & 5.1 \\
\hline Six & 2.3 \\
\hline Seven & 1.3 \\
\hline Eight & 1.1 \\
\hline Nine and above & 0.7 \\
\hline \multicolumn{2}{|l|}{$\begin{array}{l}\text { Access of Household to Electricity Connection from the } \\
\text { National Grid }\end{array}$} \\
\hline Yes & 24.5 \\
\hline No & 75.5 \\
\hline \multicolumn{2}{|l|}{ Types of Water Sources Used by Household } \\
\hline Pipe borne water supply (own tap) & 2.1 \\
\hline Public pipe borne water supply stand & 10.1 \\
\hline Bore holes & 0.3 \\
\hline Protected wells & 51.8 \\
\hline Unprotected wells & 8.0 \\
\hline Surface water & 27.3 \\
\hline Rainwater & 0.1 \\
\hline Vendor by truck & 0.4 \\
\hline \multicolumn{2}{|l|}{ Fetching of Wood by Household as a Source of Energy } \\
\hline Yes & 13.8 \\
\hline No & 86.2 \\
\hline
\end{tabular}




\begin{tabular}{|c|c|}
\hline Fetching of Water by Household & \\
\hline Yes & 10.2 \\
\hline No & 89.8 \\
\hline \multicolumn{2}{|l|}{ Ownership of Car/Motor Bike } \\
\hline Yes & 24.9 \\
\hline No & 75.1 \\
\hline \multicolumn{2}{|l|}{ Ownership of Bicycle } \\
\hline Yes & 68.2 \\
\hline No & 31.8 \\
\hline \multicolumn{2}{|l|}{ Ownership of Sewing Machine } \\
\hline Yes & 11.6 \\
\hline No & 88.4 \\
\hline \multicolumn{2}{|l|}{ Ownership of Television (TV) Set } \\
\hline Yes & 13.3 \\
\hline No & 86.7 \\
\hline \multicolumn{2}{|l|}{ Ownership of Radio } \\
\hline Yes & 59.7 \\
\hline No & 40.3 \\
\hline \multicolumn{2}{|l|}{ Ownership of Mobile Phones } \\
\hline Yes & 63.3 \\
\hline No & 36.7 \\
\hline \multicolumn{2}{|l|}{ Ownership of Computers } \\
\hline Yes & 1.2 \\
\hline No & 98.8 \\
\hline \multicolumn{2}{|l|}{$\begin{array}{l}\text { Percentage of Respondents Deriving Income from Specific } \\
\text { Source }\end{array}$} \\
\hline Agricultural Activities & 92.1 \\
\hline Wage-based Income Activities & 49.4 \\
\hline Rents & 99.2 \\
\hline Remittances & 27.4 \\
\hline Non-Farm Enterprises & 25.9 \\
\hline All Other Sources of Income & 1.4 \\
\hline \multicolumn{2}{|l|}{$\begin{array}{l}\text { Percentage of Total Household Income from Specific } \\
\text { Source }\end{array}$} \\
\hline Annual Gross Income from Agricultural Activities & 60.6 \\
\hline Annual Gross Wage Income & 27.4 \\
\hline Annual Gross Income from Rents & 8.3 \\
\hline Annual Gross Income from Other Sources & 2.3 \\
\hline Annual Gross Remittances & 1.4 \\
\hline Annual Gross Income from Non-Farm Enterprises & 0.005 \\
\hline
\end{tabular}


Table 2 summarises the socio-economic characteristics of survey respondents using average and range figures, as supplementary information to the results reported in Table 1. The average age of the household heads was 44.5 years with the age range from 15 to 95 years. The average household size of 6.0 , higher than the national average of 4.4 , but smaller than the average household size for the entire Northern region of 7.7 both obtained for the 2010 National Population Census (Ghana Statistical Service, 2013). The average distance to a source was less than a kilometer (0.71 $\mathrm{km}$ ) while the average amount of time to reach a water source was just under 20 minutes. In terms of the ownership of assets, the average size of owned land was 1.0 hectare with considerable variation based on the range from zero to 293.4 hectares.

With an average of three sources of income, the average total household income was 5,527 Ghana cedis which was quite similar to the size of average total household expenditures of 5,929 Ghana cedis. ${ }^{5}$ Total household food expenditures were 3,679.4 Ghana cedis constituting about 66.6\% (two-thirds) of the average total household income and $62.1 \%$ of the average total household expenditures. In terms of ethnicity, the Kokombas had the highest average household income but also had the highest variability of income as measured by both the standard deviation and range. The relatively high Kokomba average household income also reflected their high average household size of 7.3 ; the highest of all the groups, as compared to 5.2, 5.5, 6.2, 7.0 and 6.2 for Dagombas, Gonjas, Mamprusis, Dagartes and Bimobas, respectively.

\subsection{Determinants of Factors Influencing Income Diversification of Households}

The number of income-generating activities (NIGS) was one of the three income diversification measures used in this study. The factors influencing NIGS, ascertained through Poisson regression analysis, are presented in Table 3. Given the cross-sectional statistical nature of the data, the overall power of the model was modest with a $\mathrm{R}^{2}$ of $18.5 \%$. The likelihood ratio test indicated that the overall model was statistically significant (computed $\mathrm{p}$ value of 0.000 for rejecting the null hypothesis of zero slopes). Based on $10 \%(0.10)$ statistical significance level for the parameters used for this study, 13 out of the 27 independent variables were significant. The significant independent variables influencing NIGS were HOUSEHOLDSIZE, AGE, APPRENTICE, OWNHOUSE, ELECTRICITYCONNECTION, TIMETOWATERSOURCE, RADIO, TV, CAR, KOKOMBA, MAMPRUSI, DAGARTE and BIMOBA. The three non-ethnicity structuralism variables, SEX, CURRENTLYMARRIED, and MUSLIM, had no effect on NIGS. Four out of the six ethnicity variables had a significant effect on NIGS. Kokombas had significantly lower NIGS. Three relatively small ethnic groups, MAMPRUSI, DAGARTE, BIMOBA all had significantly higher NIGS.

As expected, increasing household size led to an increasing number of income-generating sources. The age of the household head affected NIGS in a linear matter with the number of income-generating sources increasing with increasing age. Having some apprenticeship training, either formal or informal, increased NIGS suggesting the important role of non-formal schooling human capital formation in income diversification given that formal educational level did not have any significant influence on NIGS. Ownership of a motor bike/car led to increased NIGS given the ease of travelling to market products and/or undertake other livelihood activities. The role of ICE capital inputs in income diversification was positive. Ownership of radio and television sets increased NIGS. Ownership of mobile phones was positively associated with NIGS though not significant. The capital inputs that had statistically-negative effect on NIGS were ownership of house and the time to water source. House ownership conferred on the household head an additional mean of generating income through rents and hence less NIGS was needed. Increasing time to water source was a burden on the scarce use of human time and reduced NIGS. 
Table 2. Summary of Socio-Economic Characteristics of Survey Respondents Based on Average and Range Figures Using GLSS 2013 Data for the Northern Region of Ghana

\begin{tabular}{|c|c|c|}
\hline Item & Mean & Range \\
\hline Age (years) & 44.5 & 15 to 95 \\
\hline Formal Educational Level Attained (Years of Schooling) & 2.0 & 0 to 19 \\
\hline Household Size & 6.0 & 1 to 25 \\
\hline Number of Rooms Used by Household & 2.7 & 1 to 12 \\
\hline Amount of Land Owned (acres) & 1.0 & $\begin{array}{c}0 \text { to } \\
293.4\end{array}$ \\
\hline Distance to Nearest Water Source $(\mathrm{km})$ & 0.71 & 0 to 14 \\
\hline Time to Reach Nearest Water Source (minutes) & 19.6 & 0 to 180 \\
\hline Total Annual Household Expenditures & $5,929.0$ & $\begin{array}{l}425 \text { to } \\
66,424\end{array}$ \\
\hline Total Annual Household Food Expenditures & $3,679.4$ & $\begin{array}{c}50 \text { to } \\
31,831\end{array}$ \\
\hline Number of Income-Generating Activities & 3.0 & 0 to 6 \\
\hline Annual Gross Wage Income of Household Head & 1,513 & $\begin{array}{c}0 \text { to } \\
92,560\end{array}$ \\
\hline Annual Gross Income from Non-Farm Enterprises & 2.5 & 0 to 235 \\
\hline Annual Gross Income from Agricultural Activities & 3,349 & $\begin{array}{c}0 \text { to } \\
171,265\end{array}$ \\
\hline Annual Gross Income from Rents & 460 & $\begin{array}{c}0 \text { to } \\
16,026\end{array}$ \\
\hline Annual Gross Remittances & 76.3 & $\begin{array}{l}0 \text { to } \\
6,450\end{array}$ \\
\hline Annual Gross Income from Other Sources & 127.8 & $\begin{array}{c}0 \text { to } \\
149,600\end{array}$ \\
\hline $\begin{array}{l}\text { Average total annual gross income of all households } \\
(100.0 \%)\end{array}$ & $\begin{array}{c}5,527.0 \\
(10,153)\end{array}$ & $\begin{array}{c}82 \text { to } \\
172,205\end{array}$ \\
\hline $\begin{array}{l}\text { Average total annual gross income of Dagomba } \\
\text { households }(32.0 \%)\end{array}$ & $\begin{array}{l}5,406.2 \\
(6,671.4)\end{array}$ & $\begin{array}{c}82 \text { to } \\
57,027\end{array}$ \\
\hline $\begin{array}{l}\text { Average total annual gross income of Kokomba } \\
\text { households }(23.6 \%)\end{array}$ & $\begin{array}{c}7,462.6 \\
(16,617.0)\end{array}$ & $\begin{array}{c}311 \text { to } \\
172,205\end{array}$ \\
\hline $\begin{array}{l}\text { Average total annual gross income of Gonja households } \\
(10.7 \%)\end{array}$ & $\begin{array}{c}5,024.4 \\
(9,522.1)\end{array}$ & $\begin{array}{c}92 \text { to } \\
92,818\end{array}$ \\
\hline $\begin{array}{l}\text { Average total annual gross income of Mamprusi } \\
\text { households }(6.5 \%)\end{array}$ & $\begin{array}{c}3,400.7 \\
(3,498.5)\end{array}$ & $\begin{array}{l}202 \text { to } \\
22,693\end{array}$ \\
\hline $\begin{array}{l}\text { Average total annual gross income of Dagarte households } \\
(5.6 \%)\end{array}$ & $\begin{array}{c}5,195.6 \\
(4,483.6)\end{array}$ & $\begin{array}{l}111 \text { to } \\
18,647\end{array}$ \\
\hline $\begin{array}{l}\text { Average total annual gross income of Bimoba households } \\
(4.7 \%)\end{array}$ & $\begin{array}{l}3,934.8 \\
(2,976.2)\end{array}$ & $\begin{array}{l}132 \text { to } \\
13,812\end{array}$ \\
\hline $\begin{array}{l}\text { Average total annual gross income of all other households } \\
(16.9 \%)\end{array}$ & $\begin{array}{c}4,941.3 \\
(8,343.6)\end{array}$ & $\begin{array}{c}87 \text { to } \\
70,098\end{array}$ \\
\hline
\end{tabular}

Note: The standard deviations of the average income figures are in the parentheses. 
Table 3. Results of the Poisson Count Data Regression Model Analysis of the Factors Influencing Income Diversification by Household Heads in the Northern Region of Ghana based on the 2013 GLSS Data. The Dependent Variable is NIGS.

\begin{tabular}{|c|c|c|c|}
\hline Explanatory Variable & $\begin{array}{l}\text { Parameter } \\
\text { Estimate }\end{array}$ & $\begin{array}{l}\text { Student t } \\
\text { Value }\end{array}$ & $\begin{array}{c}\text { Significance } \\
\text { Probability }\end{array}$ \\
\hline INTERCEPT & 0.758 & 8.086 & $0.000^{*}$ \\
\hline HOUSEHOLDSIZE & 0.009 & 2.233 & $0.026^{*}$ \\
\hline $\mathrm{AGE}$ & 0.007 & 1.879 & $0.060^{*}$ \\
\hline AGESQUARED & -0.00006 & -1.515 & 0.130 \\
\hline SEX & 0.010 & 0.216 & 0.829 \\
\hline YEARSOFEDUCATION & -0.003 & -1.325 & 0.185 \\
\hline APPRENTICE & 0.063 & 1.759 & 0.079* \\
\hline CURRENTLYMARRIED & 0.032 & 0.896 & 0.370 \\
\hline MUSLIM & 0.0001 & 0.004 & 0.996 \\
\hline REMITTANCE & 0.000006 & 0.669 & 0.503 \\
\hline FETCHWOOD & -0.039 & -1.378 & 0.168 \\
\hline OWNHOUSE & -0.039 & -1.740 & $0.082 *$ \\
\hline ROOMS & -0.013 & -1.627 & 0.104 \\
\hline $\begin{array}{l}\text { ELECTRICITY } \\
\text { CONNECTION }\end{array}$ & 0.049 & 2.419 & $0.016^{*}$ \\
\hline TIMETOWATERSOURCE & -0.0007 & -1.736 & $0.083^{*}$ \\
\hline MOBILEPHONE & 0.025 & 1.242 & 0.214 \\
\hline RADIO & 0.050 & 3.014 & $0.003 *$ \\
\hline TV & 0.065 & 2.094 & $0.036^{*}$ \\
\hline SEWINGMACHINE & 0.040 & 1.397 & 0.162 \\
\hline COMPUTER & -0.010 & -0.109 & 0.913 \\
\hline BICYCLE & 0.034 & 1.571 & 0.116 \\
\hline CAR & 0.051 & 2.270 & $0.023 *$ \\
\hline DAGOMBA & 0.032 & 1.030 & 0.303 \\
\hline КОКОМВА & -0.154 & 5.177 & $0.000^{*}$ \\
\hline GONJA & 0.019 & 0.501 & 0.617 \\
\hline MAMPRUSI & 0.220 & 5.774 & $0.000^{*}$ \\
\hline DAGARTE & 0.207 & 4.489 & $0.000 *$ \\
\hline BIMOBA & 0.172 & 3.427 & $0.001 *$ \\
\hline
\end{tabular}

Note: The statistical significance level for this study was $10 \%$ or 0.10 . 
Table 4 summarizes the results of the regression analysis of factors influencing income diversification based on the total household income attributed to wage-based income (SHAREWAGE). The high statistical significance of the SIGMA parameter indicated that the Tobit model was an appropriate to undertake this analysis as compared to the ordinary least squares (OLS) method given the important linkage of the SIGMA variable to the maximum likelihood procedure utilised in the Tobit estimation procedure. The 14 statistically-significant independent variables influencing SHAREWAGE were AGE, AGESQUARED, SEX, APPRENTICE, CURRENTLYMARRIED, FETCHWOOD, OWNHOUSE, MOBILEPHONE, RADIO, TV, BICYCLE, KOKOMBA, GONJA and MAMPRUSI.

The effect of age on SHAREWAGE was quadratic in nature. The maximum age level at which a decline in the relationship between age and wage-based income occurred was about 42 years (41.7). Apprenticeship was a human capital variable that had a significantly positive effect on obtaining income through wage-based work. On the other hand, the number of years of education did not have significant effect on the share of wage-based income. Ownership of the three main ICE capital inputs - radio, TV and MOBILEPHONE - had positive effect on wage-based income. Ownership of bicycles and houses, and fetching wood as an energy source were negatively related to wage-based income share.

For Table 4, the structuralism variables had mixed results. As expected from the economic theory of marriage, currently married household heads had higher share of total household income from wage-based sources due to the specialisation of labour between partners in marriage which encouraged the spouse or closely-related members within the household to seek work opportunities outside the house and the farm. Nevertheless, female household heads were less engaged in wage-based work outside the home due the culturally-structural nature of duties assigned to females for home-based work and related household-keeping tasks.

The parameter for the MUSLIM variable was not significant suggesting that religious affiliation was not a significant factor explaining this type of income diversification. The ethnic-related variables indicated different results. The Kokombas and Gonjas had relatively lower shares of their total household incomes coming from wage-based incomes while the Mamprusis had a significantly higher share of total household incomes attributed to wage-based work compared to all other groups. For the other three ethnic groups (Dagombas, Dagartes and Bimobas), there were no statistically significant differences in the wage-based shares of total household incomes as compared to all other groups.

The overall diversification index, Simpson diversification index, averaged 0.327 , ranging from 0.000 to 0.730 , indicating moderate overall diversification. Table 5 summarizes the results of the Tobit regression analysis of the factors influencing this index. The high statistical significance of the SIGMA variable indicated that the Tobit model was an appropriate model. Overall, this income diversification index was significantly and positively influenced by remittances, the number of rooms in the house, and the amount of time spent searching for water. It was negatively related to fetching wood as a source of energy supply for the household. The three non-ethnicity structuralism variables, SEX, CURRENTLYMARRIED and MUSLIM, had no effect on the overall diversification index.

For the ethnicity-based political economy variables, the two relatively big ethnic groups, Dagombas and Kokombas, had significantly lower overall income diversification index as compared to all other groups. Then, for the two smallest groups, Mamprusis and Bimobas, there was significantly higher overall income diversification as compared to all other groups. The result for the Dagombas and Kokombas could be partly attributed to the persistence of the debilitating guinea worm and bilharzia diseases, which are more common in areas inhabited by people from these two groups, and which reduce amount of time available for productive activities. 
Table 4. Results of the Tobit Regression Model Analysis of the Factors Influencing Income Diversification by Household Heads in the Northern Region of Ghana based on the Share of Total Gross Income Attributed to Earned Wage Income

\begin{tabular}{|c|c|c|c|}
\hline Explanatory Variable & $\begin{array}{l}\text { Parameter } \\
\text { Estimate }\end{array}$ & $\begin{array}{l}\text { Student t } \\
\text { Value }\end{array}$ & $\begin{array}{l}\text { Significance } \\
\text { Probability }\end{array}$ \\
\hline INTERCEPT & -0.326 & -1.933 & $0.053 *$ \\
\hline HOUSEHOLDSIZE & 0.0009 & 0.1343 & 0.893 \\
\hline AGE & 0.025 & 3.836 & $0.000 *$ \\
\hline AGESQUARED & -0.0003 & -3.991 & $0.000 *$ \\
\hline SEX & -0.206 & -2.777 & $0.005 *$ \\
\hline YEARSOFEDUCATION & 0.006 & -1.438 & 0.151 \\
\hline APPRENTICE & 0.187 & 3.107 & $0.002 *$ \\
\hline CURRENTLYMARRIED & 0.115 & 1.818 & $0.069 *$ \\
\hline MUSLIM & -0.049 & -1.158 & 0.249 \\
\hline REMITTANCE & 0.00005 & 0.243 & 0.808 \\
\hline FETCHWOOD & -0.099 & -2.050 & $0.040 *$ \\
\hline OWNHOUSE & -0.105 & -2.714 & $0.007 *$ \\
\hline ROOMS & -0.007 & -0.451 & 0.652 \\
\hline ELECTRICITYCONNECTION & 0.054 & 1.591 & 0.112 \\
\hline TIMETOWATERSOURCE & -0.0009 & -1.736 & 0.242 \\
\hline MOBILEPHONE & 0.067 & 1.875 & $0.061 *$ \\
\hline RADIO & 0.064 & 2.183 & $0.029 *$ \\
\hline $\mathrm{TV}$ & 0.167 & 3.192 & $0.001 *$ \\
\hline SEWINGMACHINE & 0.058 & 1.185 & 0.236 \\
\hline COMPUTER & -0.222 & -1.500 & 0.133 \\
\hline BICYCLE & -0.063 & -1.721 & $0.085 *$ \\
\hline CAR & 0.060 & 1.564 & 0.118 \\
\hline DAGOMBA & -0.058 & -1.158 & 0.247 \\
\hline KOKOMBA & -0.330 & 6.200 & $0.000^{*}$ \\
\hline GONJA & -0.154 & -2.389 & $0.017 *$ \\
\hline MAMPRUSI & 0.182 & 2.662 & $0.008 *$ \\
\hline DAGARTE & -0.037 & -0.501 & 0.616 \\
\hline BIMOBA & 0.107 & 1.326 & 0.185 \\
\hline SIGMA & 0.467 & 30.761 & $0.000 *$ \\
\hline
\end{tabular}

Notes: Proportion of households censored was 50.6\%. Proportion of households not censored was $49.4 \%$.

The statistical significance level for this study was $10 \%$ or 0.10 . 
Table 5. Results of the Tobit Regression Model Analysis of the Factors Influencing Overall Income Diversification by Household Heads in the Northern Region of Ghana based on the Simpson Diversification Index Using 2013 GLSS6 Data

\begin{tabular}{|c|c|c|c|}
\hline Explanatory Variable & $\begin{array}{l}\text { Parameter } \\
\text { Estimate }\end{array}$ & $\begin{array}{c}\text { Student t Test } \\
\text { Value }\end{array}$ & $\begin{array}{c}\text { Significance } \\
\text { Probability }\end{array}$ \\
\hline INTERCEPT & 0.246 & 4.585 & $0.000 *$ \\
\hline HOUSEHOLDSIZE & -0.002 & 2.233 & 0.338 \\
\hline $\mathrm{AGE}$ & 0.001 & 0.559 & 0.576 \\
\hline AGESQUARED & -0.000006 & -0.282 & 0.778 \\
\hline SEX & -0.002 & -0.075 & 0.940 \\
\hline EDUCATION & -0.0008 & -0.554 & 0.580 \\
\hline APPRENTICE & 0.026 & 1.245 & 0.213 \\
\hline CURRENTLY MARRIED & 0.005 & 0.253 & 0.800 \\
\hline MUSLIM & 0.006 & 0.449 & 0.654 \\
\hline REMITTANCE & 0.00003 & 4.433 & $0.000 *$ \\
\hline FETCHWOOD & -0.034 & -2.172 & $0.030 *$ \\
\hline OWNHOUSE & 0.012 & 0.946 & 0.344 \\
\hline ROOMS & 0.021 & 4.282 & $0.000 *$ \\
\hline $\begin{array}{l}\text { ELECTRICITY } \\
\text { CONNECTION }\end{array}$ & 0.003 & 0.302 & 0.762 \\
\hline $\begin{array}{l}\text { TIMETOWATER } \\
\text { SOURCE }\end{array}$ & 0.0004 & 1.666 & $0.096^{*}$ \\
\hline MOBILEPHONE & -0.017 & -1.430 & 0.153 \\
\hline RADIO & 0.009 & 0.888 & 0.375 \\
\hline TV & -0.011 & -0.586 & 0.558 \\
\hline SEWINGMACHINE & 0.002 & 0.147 & 0.883 \\
\hline COMPUTER & 0.046 & 0.927 & 0.354 \\
\hline BICYCLE & -0.004 & 0.334 & 0.738 \\
\hline CAR & 0.004 & 0.328 & 0.743 \\
\hline DAGOMBA & -0.046 & -2.716 & $0.007 *$ \\
\hline KOKOMBA & -0.096 & -5.617 & $0.000 *$ \\
\hline GONJA & -0.018 & 0.858 & 0.391 \\
\hline MAMPRUSI & 0.085 & 3.530 & $0.000 *$ \\
\hline DAGARTE & -0.019 & -0.727 & 0.467 \\
\hline BIMOBA & 0.053 & 1.874 & $0.061 *$ \\
\hline SIGMA & 0.173 & 48.121 & $0.000^{*}$ \\
\hline
\end{tabular}

Notes: Proportion of households censored was $1.1 \%$. The proportion of households not censored was $98.9 \%$.

The statistical significance level for this study was $10 \%$ or 0.10 . 


\subsection{Relationship Between Overall Income Diversification and Economic Welfare}

The third research question posed by our study was whether income diversification increased or decreased the level of economic welfare of households. This particular objective was inspired by the risk management theoretical framework. Winters et al. (2010) suggested that rural householders who did not have adequate non-farm income were vulnerable in terms of both income and food security. On the other hand, research workers such as de Janvry and Sadoulet (2006) showed a positive relationship between non-farm income and food security for rural households. In this study, we attempted to establish the relationship between income diversification and economic welfare of rural households in the Northern region of Ghana based on the empirical evidence provided by the relatively large available GLSS6 data. Economic welfare, as established by Ghana Statistical Service (2014), is linked to household consumption of goods and services. We answered the third research question by undertaking a standard multiple regression analysis of the relationship between economic welfare and income diversification.

This analysis was undertaken using total household expenditures (THEXPEND $D_{i}$ ) as the dependent variable. We constructed a semi-log regression model with log of total household expenditures $\left(\right.$ LTHEXPEND $_{\mathrm{i}}$ ) as the dependent variable, and SDI and logged household size as the independent variables as shown in Equation 6. SDI was chosen as the optimal diversification index for this regression analysis since it was not related to HHSIZE and dealt with the overall income diversification. The alternative broad diversification index, NIGS was directly related to HHSIZE, and was not used for the analysis reported in this section (refer to the results reported in Table 3). The analysis was repeated with household food expenditures (FOODEXPEND), as the dependent variable, in order to ascertain whether income diversification also had an effect on food consumption expenditures. This analysis is modelled using Equation 7.

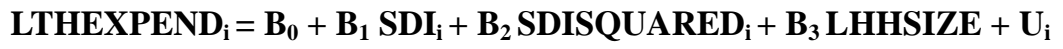

Equation 6

where SDI is the Simpson diversification index;

SDISQUARED is the square of SDI;

LHHSIZE is the natural logarithm of HHSIZE (household size);

$\mathrm{B}_{\mathrm{i}}(0,1,2$, and 3$)$ are the parameters being estimated with the sample; and

$\mathrm{U}_{\mathrm{i}}$ is the equation error term.

$$
\text { LFOODEXPEND }_{\mathrm{i}}=\mathrm{C}_{0}+\mathrm{C}_{1} \text { SDI }_{\mathrm{i}}+\mathrm{C}_{2} \text { SDISQUARED }_{\mathrm{i}}+\mathrm{C}_{3} \text { LHHSIZE }+\mathrm{V}_{\mathrm{i}}
$$

Equation 7

Where LFOODEXPEND is the natural logarithm of FOODEXPEND;

$\mathrm{C}_{\mathrm{i}}(0,1,2$, and 3$)$ are the parameters being estimated with the sample; and

$\mathrm{V}_{\mathrm{i}}$ is the equation error term.

Table 6 provides the results of the estimated LTHEXPEND model with the relevant diagnostic tests. The estimated model was correctly specified based on the Ramsey Reset test with a p value of 0.158 . The error term was also deemed to be normally distributed based on the Kolmogorov-Smirnov test with a p value of 0.142 . Hence, the estimated sample parameters could be generalised to the population parameters. There was also no significant heteroscedasticity as assessed by the Langrange-Multiplier (LM) test for heteroscedasticity with a p value of 0.780 . With $\mathrm{R}^{2}$ of around $40 \%$, the estimated model could be described as having a moderate power. The variance inflation factor figures also shown in Table 6 suggested no significant multicollinearity.

Given the correctly-specified nature of the model and its lack of any significant econometric problems, the simple model outlined in Equation 6, with its estimated results reported in Table 6, could be considered to be credible for interpretative analysis and conclusions. This assertion is based on the Keep it Sophisticatedly Simple (KISS) concept of econometric model construction which favours simple useful models which provide clear understanding as compared to more complicated and complex models (refer to Zellner, 1999).

The results from Table 6 show that all three independent variables were statistically significant in influencing the level of total household expenditures. The standardized coefficient estimates indicated that household size was the most important of the independent variables in terms of effect on the impact on total household consumption expenditures. With the variables measured in natural logarithm form, the results indicate that $1 \%$ increase in total household size would lead to $0.934 \%$ increase in total household expenditures. The effect of the overall diversification index measured by SDI had a quadratic-based impact on total household expenditures. Initially, at low to moderate levels of SDI, total household expenditures decreased. But at moderate to high levels of SDI, household expenditures increased. Given the quadratic equation-nature of the estimated function, the optimal SDI level that signals the beginning of poverty reduction based on increasing household consumption expenditures is calculated below with the estimated equation (Equation 8; Table 6).

LTHEXPEND $_{i}=7.544-1.918 S D I+1.953 S D I S Q U A R E D_{i}+0.934$ LHHSIZE $+U_{i}$ Equation 8 
We differentiate Equation 8 with respect to SDI in order to get the optimal SDI level which is denoted below.

$-1.918+(2 * 1.953)$ SDI $=0$ or $1.918=3.906$ SDI. The optimal SDI is 0.491 derived from $1.918 / 3.906$.

The optimal SDI of 0.491 is equivalent to an HHCI value of 0.509 (1-0.491). The corresponding optimal SDI figure for total food expenditures was $\mathbf{0 . 5 4 6}$. Specifically, our results showed that overall household diversification should be above 0.491 SDI to achieve increases in total household consumption expenditures. As reported earlier, the mean SDI for the 1,194 households was 0.327 . Further, only $23.7 \%$ of the households had SDI higher than the optimal 0.491 level for total consumption expenditures, and only $14.2 \%$ of the households had SDI higher than the optimal 0.546 level for food expenditures. These results indicated the need for more income diversification to increase total consumption expenditures and food expenditures, and reduce poverty levels for rural households in the Northern Region of Ghana.

Table 6. Standard Multiple Regression Analysis of Total Household Expenditures Versus the Overall Diversification Index (SDI) and Household Size for the Northern Region of Ghana Based on 2013 GLSS6 Data

Dependent Variable is LTHEXPEND (natural logarithm of total household consumption expenditures)

\begin{tabular}{|l|c|c|c|c|}
\hline \multicolumn{1}{|c|}{$\begin{array}{c}\text { Explanatory } \\
\text { Variable }\end{array}$} & $\begin{array}{c}\text { Unstandardised Regression } \\
\text { Parameter Estimate }\end{array}$ & $\begin{array}{c}\text { Standardised Regression } \\
\text { Parameter Estimate }\end{array}$ & $\begin{array}{c}\text { Probability Level of } \\
\text { Significance }\end{array}$ & $\begin{array}{c}\text { Variance } \\
\text { Inflation } \\
\text { Factor }\end{array}$ \\
\hline INTERCEPT & 7.544 & 0.000 & 0.760 & 0.000 \\
\hline SDI & -1.918 & -0.438 & $0.000^{*}$ & 16.441 \\
\hline SDISQUARED & 1.953 & 0.309 & $0.001^{*}$ & 16.245 \\
\hline LHHSIZE & 0.934 & 0.650 & $0.000^{*}$ & 1.053 \\
\hline
\end{tabular}

\section{Notes}

F value

$250.217^{*}$

$\mathrm{R}^{2}$

$0.402 *$

Adjusted $\mathrm{R}^{2}$

$0.400^{*}$

Probability significance level of Ramsey Reset Test for correct model specification

based on the null hypothesis of adequately-correct model specification

Probability significance level of the Kolmogorov-Smirnov test for the normality of

the error term based on the null hypothesis of normal error term

Probability significance level of Langrange-Multiplier test of no heteroscedasticity

based on the null hypothesis of homoscedasticity or no heteroscedasticity

0.780

* denotes statistical significance of the parameter at the $10 \%$ level.

Table 7 provides the results of the estimated LFOODEXPEND model with the relevant diagnostic tests. Similar to the results for LTHEXPEND model, the estimated model was correctly specified and the error term was normally distributed. Further, there was no significant heteroscedasticity and multicollinearity. The power of the estimated model was also moderate with $\mathrm{R}^{2}$ of 0.382 . The results from Table 7 also indicated a quadratic relationship between overall income diversification index measured by SDI and household food consumption expenditures. Given low to moderate level of income diversification, food consumption expenditures declined. However, with moderate to high levels of income diversification, food consumption expenditures increased. The standardized coefficient estimates indicated that household size was the most important of the independent variables in terms of effect on household food consumption expenditures. One percent increase in total household size would lead to $0.896 \%$ increase in food consumption expenditures. 
Table 7. Standard Multiple Regression Analysis of Household Food Expenditures Versus the Overall Diversification Index (SDI) and Household Size for the Northern Region of Ghana Based on 2013 GLSS6 Data

Dependent Variable is LFOODEXPEND (natural logarithm of household food expenditures)

\begin{tabular}{|l|c|c|c|c|}
\hline $\begin{array}{c}\text { Explanatory } \\
\text { Variable }\end{array}$ & $\begin{array}{c}\text { Unstandardised Regression } \\
\text { Parameter Estimate }\end{array}$ & $\begin{array}{c}\text { Standardised Regression } \\
\text { Parameter Estimate }\end{array}$ & $\begin{array}{c}\text { Probability Level of } \\
\text { Significance }\end{array}$ & $\begin{array}{c}\text { Variance } \\
\text { Inflation } \\
\text { Factor }\end{array}$ \\
\hline INTERCEPT & 7.213 & 0.000 & 0.760 & 0.000 \\
\hline SDI & -2.197 & -0.506 & $0.000^{*}$ & 16.441 \\
\hline SDISQUARED & 2.011 & 0.321 & $0.001^{*}$ & 16.245 \\
\hline LHHSIZE & 0.896 & 0.630 & $0.000^{*}$ & 1.053 \\
\hline
\end{tabular}

Notes

F value

$230.310^{*}$

$\mathrm{R}^{2}$

Adjusted $\mathrm{R}^{2}$

Probability significance level of Ramsey Reset Test for correct model specification

based on the null hypothesis of adequately-correct model specification

Probability significance level of the Kolmogorov-Smirnov test for the normality of the error term based on the null hypothesis of normal error term

Probability significance level of Langrange-Multiplier test of no heteroscedasticity based on the null hypothesis of homoscedasticity or no heteroscedasticity

* denotes statistical significance of the parameter at the $10 \%$ level.

\section{Conclusions and Policy Recommendations}

\subsection{Conclusions}

We analysed the income diversification activities of 1,194 randomly-selected rural households in the Northern Region of Ghana using data from the sixth round of the Ghana Living Standards Survey undertaken by the Ghana Statistical Service which was completed at the end of 2013. We established six main broad sources of income-generating activities as follows: (1) crop and livestock (farm) production, (2) home or community-based non-farm enterprises, (3) wage-based income activities through undertaking selling one's labour time on work activities outside the household, (4) property-based rental income such as those derived from renting rooms of the household property and the renting of various assets and equipment for farming and non-farming purposes, (5) remittances from various social networks, and (6) other sources.

The number of income-generating activities undertaken by households was significantly related to the size of the household, previous apprenticeship training acquired by the household head, ownership of a motor bike/car, and ownership by the household of specific physical assets that also provide ICE services namely radio and television sets. The capital inputs that had statistically negative effect on the number of income-generating activities were ownership of house and the time to water source. With regards to ethnicity, Kokombas had significantly lower number of income-generating activities while the relatively smaller ethnic groups, Mamprusis, Dagartes and Bimobas, all had significantly higher income-generating activities. Religious affiliation and sex of the household head did not affect the number of income-based activities.

The share of wage-based income in the total household income was significantly related to the age of the household head in a quadratic-equation manner with the optimal peak year established as 42 years. This share was also related to the previous apprenticeship training acquired by the household head and ownership of all three ICE physical capital 
inputs namely mobile phone, radio and television sets. Ownership of bicycles and houses, and fetching wood as an energy source were negatively related to wage-based share. Married household heads had a higher level of their total income coming from wage-based incomes than non-married counterparts. However, female household heads were less engaged in wage-based work outside the home. Concerning ethnicity, Kokombas and Gonjas had relatively lower shares of their total household incomes coming from wage-based incomes as compared to all other groups. Mamprusis had significantly higher shares of total household incomes attributed to wage-based work. For the other three ethnic groups (Dagombas, Dagartes \& Bimobas), there were no statistically significant differences in the wage-based shares of total household incomes as compared to all other groups.

The overall income diversification index, as established by the Simpson index, was significantly and positively influenced by remittances, the number of rooms in the house, and the amount of time spent fetching for water. It was negatively related to fetching wood as a source of energy supply for the household. The three non-ethnicity structuralism political economy variables, SEX, MARRIED and MUSLIM, had no significant effect on the overall diversification index. With regards to ethnicity, the overall income diversification index was significantly lower for the two biggest ethnic groups, Dagombas and Kokombas, as compared to all other groups. However, for the two relatively small ethnic groups, Mamprusis and Bimobas, there was significantly higher overall income diversification as compared to all other groups.

Finally, we showed that at relatively low levels, income diversification was associated with both decreasing total household consumption expenditures and total household food expenditures. However, at relatively higher levels, we established that income diversification increased both food consumption and total household expenditures, providing for both increased income security and food security to rural households. It appears that income diversification might not have been extensive enough in the Northern Region of Ghana to drive down poverty considerably as compared to the other regions. This slow progress could be due to the relatively lower Community and State support systems available to households in the region, and also possibly due to the greater intensity of communal and inter-ethnic conflicts in the region as reported by Sulemana (2009).

\subsection{Policy Recommendations}

First, our study established that previous apprentice training had significant positive impact on income diversification while formal educational attainment had no significant impact on income diversification, regardless of which of the three diversification measures that was used. Given that the Northern Region has had free formal educational programmes financed by the State including free senior high school boarding and lodging facilities since political independence in 1957, our study suggests that the necessarily-high adequate levels of income diversification required to drive down poverty levels significantly would require considerable enhancement of apprenticeship and vocational programmes for rural households in the region.

Given that free senior high school programme, with comprehensive free boarding and lodging facilities, was extended to all other parts of the country in 2017, it is imperative for the government to consider enhanced vocational and apprenticeship training for senior high school graduates upon completion of their studies as the vast majority of these students ( $80 \%$ or currently about 400,000 annually) cannot be absorbed by private and public universities and other tertiary institutions in Ghana. As pointed by Anaman (2018), such students who have been nurtured in a programme of entitlements may not be willing to enter into the relatively non-lucrative agricultural occupations in large numbers. This factor could create conditions for increased youth unemployment with attendant increase in crimes unless well-designed apprenticeship, vocational and technical programmes are instituted to deal with the numerous high school graduates not able to enter universities and other tertiary institutions.

Second, the findings of our representative regional study have some important bearings on current government policies aimed at improving the living conditions of people in the northern parts of the country through programmes such as One-Village-One-Dam and One-District-One-Factory schemes which have had very limited success since their introduction over the last two years and seven months. We have shown that relatively high household income diversification is required to reduce poverty and increase food security for rural households. This relatively high household income diversification is likely to occur in a more extensive way if the government also advances enhanced development policies in the Northern part of Ghana aimed at the services sector of the economy such as rural tourism.

Finally, like all human livelihood activities, income diversification activities can only be undertaken under conditions of peace and good security. Recent increases in crimes in Ghana, such as kidnappings of local and overseas citizens, and communal violence in different parts of the country, including the Northern Region, indicate serious security concerns for livelihood activities. Government security efforts need to be increased, especially in the area of intelligence work, to prevent and reduce conflicts in Ghana. 


\section{References}

Agyeman, S., Archibald, B., Brimpong, S. A., \& Onumah, E. E. (2014). Determinants of income diversification in the Western Region of Ghana, Quarterly Journal of International Agriculture, 53(1), 55-72.

Amurtiya, A., Lumbonyi, C. A., Abdullah, A., Olayiwola, S. A., Yaduma, Z. A., \& Abdullahi, A. (2016). "Livelihood diversification and income: a case study of communities along the Kiri Dam, Adamawa State, Nigeria", Journal of Agribusiness and Rural Development, 4, 483-492. https://doi.org/10.17306/JARD.2016.75

Anaman, K. A. (1988). African Farm Management: Principles and Applications with Examples. Accra: Ghana Universities Press.

Anaman, K.A. \& Kassim, H.M. (2006). Marriage and female labour supply in Brunei Darussalam: a case study of urban women in Bandar Seri Begawan. The Journal of Socioeconomics, 35(5), 797-812.

Anaman, K. A. (2018). Analysis of Unemployment in Ghana Using District Level National Population Census Data. Accra: Institute for Fiscal Studies.

Anonymous (2019). Assessing Farm Gate Pricing and Incomes of Cocoa Farmers: A Case Study of Cocoa Farmers in the Agona East District. Accra, Ghana: SEND GHANA, https://tiny.cc/y4nw7y, accessed on 12 June 2019.

Ashley, C., \& Carney, D. (1999). Sustainable Livelihoods: Lessons from Early Experience. London: Department for International Development, Government of the United Kingdom.

Awo, M. A., \& Anaman, K.A. (2015). Political economy analysis of the production and marketing of shea nut products by women in the Northern Region of Ghana. Research in World Economy, 6, 1-17. https://doi.org/10.5430/rwe.v6n4p1

Anaman, K. A., \& Bukari, G. A. (2019). Political economy analysis of the macroeconomic impact of national elections in Ghana during the fourth republican era, 1992 to 2016. Applied Economics and Finance, 6, 28-44. https://doi.org/10.11114/aef.v6i3.4202

Barrett, C. B., \& Reardon, T. (2000). Asset, Activity, and Income Diversification among African Agriculturalists: Some Practical Issues. Ithaca, New York: Cornell University. https://doi.org/10.2139/ssrn.257344

Becker, G. S. (1973). A theory of marriage. Part 1. Journal of Political Economy, 81(4), 813-846. https://doi.org/10.1086/260084

Becker, G. S. (1974). A theory of marriage. Part 2. Journal of Political Economy, 82(2), 511-526. https://doi.org/10.1086/260287

Bird, K., \& Shepherd, A. (2003). Livelihoods and chronic poverty in semi-arid Zimbabwe. World Development, 31(3), 591-610. https://doi.org/10.1016/S0305-750X(02)00220-6

Buadi, D. K., Anaman, K. A., \& Kwarteng, J. A. (2013). Farmers' perceptions of the quality of extension services provided by non-governmental organizations in two municipalities in the Central Region of Ghana. Agricultural Systems, 120, 20-26. https://doi.org/10.1016/j.agsy.2013.05.002

Buah, F. K. (1998). A History of Ghana. London: MacMillan Education Limited.

Canagarajah, S., Newman, C. B., \& Bhattamishra, R. (2001). Non-farm income, gender, and inequality: Evidence from rural Ghana and Uganda. Food Policy, 26(4), 405-420. https://doi.org/10.1016/S0306-9192(01)00011-2

Daud, A. S., Awoyemi, T. T., Omotoso, A. B., \& Omotayo, A. O. (2018). Human capital and income diversification among crop farmers in rural Oyo State, Nigeria. Journal of Agribusiness and Rural Development, 3, 251-260. https://doi.org/10.17306/J.JARD.2018.00422

Davidson, B. (1972). History of Africa. London: Spring Books.

Davis, B., Winters, P., Reardon, T., \& Stamoulis, K. (2009). Rural nonfarm employment and farming: household-level linkages. Agricultural Economics, 40(2), 119-123. https://doi.org/10.1111/j.1574-0862.2009.00374.x

De Janvry, A., \& Sadoulet, E. (2006). Progress in the modeling of rural households' behavior under market failures. In A. De Janvry \& R. Kanbur (Eds.), Poverty, Inequality and Development, 155-181. New York, NY: Springer. https://doi.org/10.1007/0-387-29748-0_9

Diamond, J. (1999). Guns, Germs and Steel: The Fate of Human Societies. New York: W. W. Norton.

Dzanku, F. M., Jirström, M., \& Marstorp, H. (2015). Yield gap-based poverty gaps in rural Sub-Saharan Africa. World Development, 67, 336-362. https://doi.org/10.1016/j.worlddev.2014.10.030

Ellis, A. B. (1894). A History of the Gold Coast of West Africa. London: Chapman and Hall. 
https://doi.org/10.1080/00220380410001673175

Ellis, F., \& Freeman, H. A. (2006). Rural livelihoods and poverty reduction strategies in four African countries. Journal of Development Studies, 40(4), 1-30.

Gatawa, M. M. (2013). Expansion of the Hausa migrant community in Lagos, Nigeria, 1970-2007. Ghana Social Science Journal, 10( 1 and 2), 129-155.

Ghana Statistical Service (GSS) (2013). 2010 National Population and Housing Census: National Analytic Report. Accra: GSS.

Ghana Statistical Service (GSS) (2014). Ghana Living Standards Survey Round 6 (GLSS) 6 Main Report. Accra: GSS.

Ghana Statistical Service (GSS) (2019). Annual 2013 to 2018 GDP, April 2019. Accra: GSS.

Gujarati, B.N. (2003). Basic Econometric Methods Fourth Edition. New York: Prentice Hall.

Haggblade, S., Hazell, P., \& Reardon, T. (2010). The rural non-farm economy: prospects for growth and poverty reduction. World Development, 38(10), 1429-1441. https://doi.org/10.1016/j.worlddev.2009.06.008

Hall, M. \& Tideman, N. (1967). Measures of concentration. Journal of the American Statistical Association, 62: 162-168.

Hall, B. H., \& Cummins, C. (2009). Time Series Processor (TSP) Version 5 Reference Manual. Palo Alto, California: TSP International.

Herfindahl, O. C. (1950). Concentration in the U.S. Steel Industry. New York: Columbia University.

Herfindahl, O. C. ( 1959). Copper Costs and Prices: 1870 - 1957. Baltimore: The John Hopkins Press.

Hirschman, A. O. (1945). National Power and the Structure of Foreign Trade. Berkeley: University of California Press.

Hirschman, A. O. (1964). The paternity of an index. American Economic Review, 54(5), 761-762.

Kah, H.K. (2013). Palm produce trade in Cameroon's Cross River region from early 1800s to 1961. Ghana Social Science Journal, 10(1\&2), 107-128.

Knight, F. H. (1921). Risk, Uncertainty, and Profits. Boston, Massachusetts: Hart, Schaffner and Marx, Houghton Mifflin.

Kolmogorov, A. (1933). Sulla determinazione empirica di una legge di distribuzione. G. Ist Ita. Attuari, 4, 83-91.

Lynch, H. R. (1968). Introduction. In J.M. Sarbah (Ed.), Fante National Constitution and Law Reports. London: Frank Cass and Company.

Mcbrearty, S., \& Brooks, A. S. (2000). The revolution that wasn't: a new interpretation of the origin of modern human behaviour", Journal of Human Evolution, 39(5), 453-563. https://doi.org/10.1006/jhev.2000.0435

Maddala, G. S. (1992). Introduction to Econometrics, Second Edition. New York: Macmillan.

Markowitz, H. (1952). Portfolio selection. Journal of Finance, 7(1), 77-91. https://doi.org/10.1111/j.1540-6261.1952.tb01525.x

Minot, N., Epprecht, M., Anh, T. T. T., \& Trung, L. Q. (2006). Income Diversification and Poverty in the Northern Upland of Vietnam. Research Report No 145. Washington, DC: International Food Policy Research Institute.

Mohammed, S. J., \& Anaman, K. A. (2003). Analysis of causality links between aggregate women labour force and the divorce rate in Brunei Darussalam. In Applied Economic Analysis in Brunei Darussalam: Evaluation of Economic Growth and Trade, Microeconomic Efficiency and Analysis of Socio-economic Problems. Bandar Seri Begawan: Universiti Brunei Darussalam, 164-182.

Niehof, A. (2004). The significance of diversification for rural livelihood systems. Food Policy, 29, 321-338. https://doi.org/10.1016/j.foodpol.2004.07.009

Nti, K. (2002). An overview of the ding dong relationship between the colonial government and the people of Cape Coast. Nordic Journal of African Studies, 11(1), 1-37.

Ramsey, J. S. (1969). Tests for specification errors in classical linear least squares regression. Journal of the Royal Statistical Society, Series B, 350-371. https://doi.org/10.1111/j.2517-6161.1969.tb00796.x

Sackrey, C., Schneider, G., \& Knoedler, J. (2016). Introduction to Political Economy Eighth Edition. Boston: Dollars and Sense, Economic Affairs Bureau.

Simpson, E. H. (1949). Measurement of diversity. Nature, 163, 688. https://doi.org/10.1038/163688a0

Smirnov, N. (1948). Table for estimating the goodness of fit of empirical distributions. Annals of Mathematical 
Statistics, 19(2), 279-281. https://doi.org/10.1214/aoms/1177730256

Start, D. (2001). The rise and fall of the rural non-farm economy: Poverty impacts and policy options. Development Policy Review, 19(4), 491-505. https://doi.org/10.1111/1467-7679.00147

Sulemana, M. (2009). Understanding the causes and impacts of conflicts in the Northern region of Ghana. Ghana Policy Journal, 3, 110-139.

Sultana, N., Hossain, E., \& Islam, K. (2015). Income diversification and household well-being: a case study in rural areas of Bangladesh. Int. J. Bus. Econ. Res., 4(3), 172-179. https://doi.org/10.11648/j.ijber.20150403.20

Timmer, C. P. (2009). A World Without Agriculture: The Structural Transformation in Historical Perspective. Washington, DC: AEI Press.

Tobin, J. (1958a). Liquidity preference as behavior towards risk. Review of Economic Studies, 25(2), 65-86. https://doi.org/10.2307/2296205

Tobin, J. (1958b). Estimation of relationships for limited dependent variables. Econometrica, 26, 24-36. https://doi.org/10.2307/1907382

Von Neumann, J., \& Morgenstern, O. (1944). Theory of Games and Economic Behaviour. Princeton: Princeton University Press.

Wan, J., Li, R., Wang, W., Liu, Z., \& Chen, B. (2016). Income diversification: a strategy for rural region risk management. Sustainability, 8, 1064-1075. https://doi.org/10.3390/su8101064

Ward, W. E. F. (1948). A History of the Gold Coast. London: George Allen and Unwin.

Wikipedia (2019). Human Evolution. Accessed 12 May 2019.

Winters, P., Essam, T., Zezza, A., Davis, B., \& Carletto, C. (2010). Patterns of rural development: a cross-country comparison using microeconomic data. Journal of Agricultural Economics, 61(3), 48-63. https://doi.org/10.1111/j.1477-9552.2010.00265.x

World Bank. (2013). Growing Africa: Unlocking the Potential of Agribusiness (AFTFP/AFTAI). Washington, DC: The World Bank.

Zellner, A. (1999). Keep it Sophisticatedly Simple. Berkeley: Department of Agricultural and Resource Economics and Policy, University of California.

Zurek, K. (2018). Confirmed: results of the 2018 referendum on new regions. Daily Graphic, 28 December Edition, accessed at www.graphic.com.gh/news/politics, accessed on 1 June 2019.

\section{Endnotes}

${ }^{1}$ The 17 traditional African states in the Gold Coast area which signed the 6 March 1844 joint security agreement with the Government of the United Kingdom of Great Britain for protection against other traditional African states and various non-British European nation states were (1) Abora, (2) Agona (Agona Nsaba), (3) Ajumako, (4) Anomabu, (5) Asikuma (Breman Asikuma), (6) Assin Attandasu, (7) Assin Apemanim, (8) Cape Coast, (9) Denkyira, (10) Dixcove, (11) Dominase, (12) Ekumfi, (13) Gomoa, (14) James Town (Accra), (15) Twifo, (16) Wassa Amenfi, and (17) Wassa Fiase (Ellis, 1894; Ward, 1948; Davidson, 1972).

${ }^{2}$ King Aggrey of Cape Coast is credited as the first African leader of the Gold Coast to initiate a movement for self-government based on his work starting in March 1865. His movement continued after his death at the end of 1865 till 1897, culminating in major protests in Cape Coast, including one against the introduction of a poll tax in 1873 by the local British Governor. These protests forced the British Government to move the capital of its Gold Coast State from Cape Coast to Accra in 1873. The second major organization that pushed for political independence was the Aborigines Rights Protection Society (ARPS) which was founded on 17 May 1897 by Lawyer John Mensah Sarbah and a group of intellectuals and chiefs mainly from Cape Coast. The ARPS was active for 40 years from 1897 to mid-1930s, several decades after the death of Mr. Sarbah. The third organization was the United Gold Coast Convention (UGCC), founded by Mr. George Grant, and a group of lawyers and intellectuals in August 1947. The UGCC existed for only three years as it broke up in 1950 due to internal divisions and its weak linkages to the masses especially the youth. Therefore it could not contest the first national election in the Gold Coast held on 8 February 1951 (Davidson, 1972; Buah, 1998).

The most important independence movement was the Convention People's Party (CPP), founded in June 1949 by Dr. Kwame Nkrumah. The CPP led the Gold Coast to independence on 6 March 1957 winning all three national elections organized by the British Colonial Government in 1951, 1954 and 1956. Ghana became a Republic on 1 July 1960, after national presidential election-cum-republican-referendum held on 27 April 1960, organized under the last British 
Governor-General in Ghana. Dr. Nkrumah won the election by $89.1 \%$ of the total votes cast against the other candidate contesting the election, Dr. Joseph Boakye Danquah, of the United Party, who received 10.9\% of the total votes. The turnout rate of the election was $54.4 \%$ based on 1,140,699 votes cast out of the 2,098,651 registered voters (Buah, 1998).

${ }^{3}$ The referenda on the creating of new regions were held on 27 December 2018 in four regions of Ghana - Brong Ahafo, Northern, Volta and Western Regions. These referenda, organized by the Electoral Commission of Ghana, resulted in the creation of six additional new regions to bring the total number of regions to 16 . The referenda passed with an approval rate of $99.4 \%$. The turnout was $84.0 \%$ based on $1,855,458$ votes cast out of 2,208,858 registered voters (Zurek, 2018).

${ }^{4}$ The Dagombas, comprising of $4.3 \%$ of the population of Ghana, are one of the ten major social/ethnic groups in Ghana, out of the 89 social/ethnic groups identified by the Ghana Statistical Service (2013). The Dagomba kingdom is the second largest kingdom in Ghana, founded over 600 years ago. Its capital town is Yendi and its language, Dagbani, is one of the 14 official local languages. The ten large social/ethnic groups in Ghana are (1) Asantes (14.8\%), (2) Ewes (12.7\%), (3) Fantes (9.9\%), (4) Bonos (4.6\%), (5) Dangmes (4.3\%), (6) Dagombas (4.3\%), (7) Gas (3.4\%), (8) Akyems (3.4\%), (9) Akuapems (2.9\%), and (10) Kokombas (2.7\%). These ten social/ethnic groups constitute about $63 \%$ of the population. The remaining 79 social/ethnic group constitute about $37 \%$ of the population.

${ }^{5}$ In 2013, one United States dollar was worth on average 1.92 Ghana cedis.

\section{Copyrights}

Copyright for this article is retained by the author(s), with first publication rights granted to the journal.

This is an open-access article distributed under the terms and conditions of the Creative Commons Attribution license which permits unrestricted use, distribution, and reproduction in any medium, provided the original work is properly cited. 